\title{
スキン・コア型複合体中における染料の拡散 ${ }^{*}$
}

\author{
山形大学工学部丁子敬子・唐沢幹雄 \\ 長沢仁志・松浦 功
}

\section{DIFFUSION OF DYE IN THE COMPOSITE MEDIA OF SKIN-CORE TYPE}

\section{By Noriko Choit, Mikio Karasawa, Hitoshi Nagasawa, and Isao Matsuura}

(Faculty of Engineering, Yamagata University, Yonezawa, T 992, Japan)

Diffusion of dye in the composite media with skin and core is investigated in non-steady state. The composite membrane considered here is symmetric with respect to $x=h$, where $h$ is the half thickness of the membrane. The region $0 \leqq x \leqq h_{1}$ is of substrate 1 (skin) and $h_{1} \leqq x \leqq h$ is of substrate 2 (core). $C_{1}$ and $D_{1}$ denote the concentration and diffusion coefficient in substrate 1, and $C_{2}, D_{2}$ are the corresponding quantities in substrate 2. $C_{\mathrm{s} 1}, C_{\mathrm{s} 2}$ are the surface concentrations in substrates 1 and 2 . In the case that $D_{\mathrm{i}}$ and $C_{\mathrm{si}}$ are constant, the differential equations to be solved are

$$
\frac{\partial C_{1}}{\partial t}=D_{1} \frac{\partial^{2} C_{1}}{\partial x^{2}}\left(0 \leqq x \leqq h_{1}\right), \frac{\partial C_{2}}{\partial t}=D_{2} \frac{\partial^{2} C_{2}}{\partial x^{2}}\left(h_{1} \leqq x \leqq h\right) .
$$

The initial and boundary conditions are assumed as follows:

$$
\begin{aligned}
& C_{1}=0\left(0 \leqq x \leqq h_{1}, t=0\right), C_{2}=0\left(h_{1} \leqq x \leqq h, t=0\right), \\
& C_{1}=C_{\mathrm{s} 1}(x=0, t>0), \frac{C_{1}}{C_{2}}=\frac{C_{\mathrm{s} 1}}{C_{\mathrm{s} 2}}\left(x=h_{1}, t>0\right), \\
& D_{1} \frac{\partial C_{1}}{\partial x}=D_{2} \frac{\partial C_{2}}{\partial x}\left(x=h_{1}, t>0\right), \frac{\partial C_{2}}{\partial x}=0(x=h, t>0) .
\end{aligned}
$$

The final results are

$$
\begin{gathered}
\frac{C_{1}}{C_{\mathrm{s} 1}}=1+2 \sum_{n=1}^{\infty} \frac{\cos \mu(1-A) \beta_{n} \cos (A-X) \beta_{n}-\sigma \sin \mu(1-A) \beta_{n} \sin (A-X) \beta_{n}}{g^{\prime}\left(\beta_{n}\right)} \frac{\exp \left(-D_{1} \beta_{n}^{2} t / h^{2}\right)}{\beta_{n}} \\
(0 \leqq X \leqq A) \\
\frac{C_{2}}{C_{\mathrm{s} 2}}=1+2 \sum_{n=1}^{\infty} \frac{\cos \mu(1-X) \beta_{n}}{g^{\prime}\left(\beta_{n}\right)} \frac{\exp \left(-D_{1} \beta_{n}^{2} t / h^{2}\right)}{\beta_{n}} \quad(A \leqq X \leqq 1)
\end{gathered}
$$

where $\mu=\sqrt{D_{1} / D_{2}}, \quad \sigma=C_{\mathrm{s} 2} / C_{\mathrm{s} 1} \mu, A=h_{1} / h, X=x / h, \beta_{n}$ are the positive roots of $g(\beta)=0$, and $g^{\prime}\left(\beta_{n}\right)=\{d g(\beta) / d \beta]_{\beta=\beta_{n}}$.

$$
g(\beta)=\cos \mu(1-A) \beta \cos A \beta-\sigma \sin \mu(1-A) \beta \sin A \beta
$$

The amounts of dye $M_{\mathrm{t} 1}, M_{\mathrm{t} 2}$ in the substrates 1,2 are derived by integrating the equations (1) and (2) with respect to $X$.

\footnotetext{
*との報文老「复而体中に括ける染料の搪散に関する研究(第 2 報). Studies on the diffusion of dye in composite media (Part 2)」とする。
} 


$$
\begin{aligned}
& \frac{M_{t 1}}{M_{\infty 1}}=1+\frac{2}{A} \sum_{n=1}^{\infty} \frac{\cos \mu(1-A) \beta_{n} \sin A \beta_{n}+\sigma \sin \mu(1-A) \beta_{n}\left(\cos A \beta_{n}-1\right)}{g^{\prime}\left(\beta_{n}\right)} \times \frac{\exp \left(-D_{1} \beta_{n}^{2} t / h^{2}\right)}{\beta_{n}^{2}} \\
& \frac{M_{t 2}}{M_{\infty 2}}=1+\frac{2}{\mu(1-A)} \sum_{n=1}^{\infty} \frac{\sin \mu(1-A) \beta_{n}}{g^{\prime}\left(\beta_{n}\right)} \frac{\exp \left(-D_{1} \beta_{n}^{2} t / h^{2}\right)}{\beta_{n}^{2}}
\end{aligned}
$$

where $M_{\infty 1}=C_{\mathrm{si}} h_{1}, M_{\infty 2}=C_{\mathrm{s} 2}\left(h-h_{1}\right)$

The total amount $M_{\mathrm{t}}^{\mathrm{c}}$ in the composite is

$$
\frac{M_{\mathrm{t}}^{\mathrm{c}}}{M_{\infty}^{\mathrm{c}}}=\frac{M_{\mathrm{t} 1}+M_{\mathrm{t} 2}}{M_{\infty 1}^{\mathrm{c}}+M_{\infty 2}}
$$

where $M_{\infty}^{c}$ is the amount of dye in the composite at equilibrium.

The films of nylon $6\left(\mathrm{~N}_{6}\right)$ and cellulose diacetate $(\mathrm{Ac})$ are used to make a composite film roll as a model with skin and core. One of the films is rolled 5 times around a glass rod (radius $=1 \mathrm{~cm}$ ) and the cther is also rolled same times on the film roll. The composite film rolls are represented by $5 \mathrm{~N}_{6}-5 \mathrm{Ac}$ and $5 \mathrm{Ac}-5 \mathrm{~N}_{6}$ depending on the sequence of the films. These film rolls are dyed at $60^{\circ} \mathrm{C}$ in the aqueous solution of $p$-aminoazobenzene (PAAB),

The concentration distributions of PAAB in the composite film rolls agreed with the theoretical curves calculated by the equations (1) and (2). The dyeing rate of the composite $5 \mathrm{~N}_{6}-5 \mathrm{Ac}$ was larger than that of $5 \mathrm{Ac}-5 \mathrm{~N}_{6}$, and those were in accordance with the theoretical values on the basis of the equations (3) (5). Some of the properties for the dyeing curves of the composite membranes were described.

The analytical solutions of diffusion equations are also derived for a semi-infinite composite medium. Experimental results agreed with the solutions.

(Received October 28, 1977)

\section{1. 緒言}

前報り沈执いて，2種のフィルムを重ねて巻いた反復 型複合巻層の染色により，ての巻層内部の染料濃度分布 蜘散距離に対して單調減少とはならず，外層の基質 1 よりも内層の基暂 2 の方が高濃度になる場合があるとと を見出した。

そこで本報执いては，複合体の各基䉓中における染 料濃度分布上 2 㮔の基質の境界面に拈ける濃度の不連続 性について娭討する。本報で用いる複合体は 2 種の基質 の境界面が 1 つで，内部上外部に分加れているあのとす る。このような複合体をとこではスキン・コア型複合体 と呼かとととする。

スキン・コア型複合体におりる搪散について, 数学的 な解を求実測值と合せて考察するととは，前報の反復

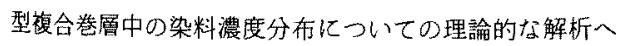
の手掛加りとなろう。また，とのような缼合体における 染料の拡散举動は，実際の染色上からも興昧ある問題で ある。

\section{2. スキン・コア型複合体における染料漕度分布}

2.1 スキン・コア型半無限体中の染料浱度分布 図1aに示すような，一方は厚さ $h_{1}$ で他方は半無限体

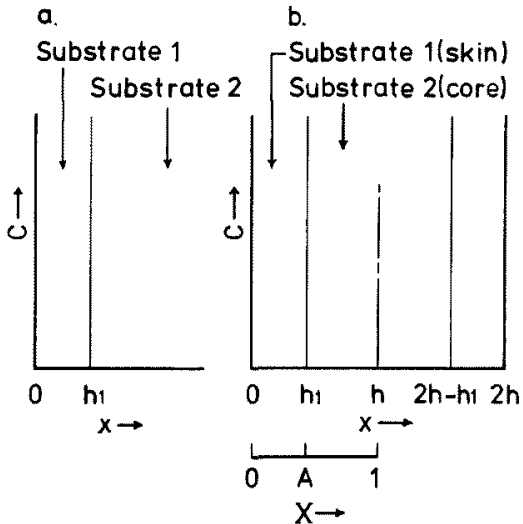

Fig. 1 Composite media of skin-core type.

(a) Semi-infinite medium, (b) Membrane

である2つの基質からなる複合体を考える。ただし，各 基質に打いては，染料の搪散は浱度に依存しない Fick 型であるとする。この複合体中の搪散方程式は（1）およ び(2)式となる。

$$
\frac{\partial C_{1}}{\partial t}=D_{1} \frac{\partial^{2} C_{1}}{\partial x^{2}}\left(0 \leqq x \leqq h_{1}\right)
$$




$$
\frac{\partial C_{2}}{\partial t}=D_{2} \frac{\partial^{2} C_{2}}{\partial x^{2}} \quad\left(h_{1} \leqq x\right)
$$

ここでCは染料濃度，Dは拡散係数， $x$ は表面からの距離， $t$ は拡散時間で，添字 $1 ， 2$ はそれぞれ㫷質 $1 ， 2$ を示す。 初期条件は(3)扔よび(4)式とする。

$$
\begin{array}{ll}
C_{1}=0 & \left(0 \leqq x \leqq h_{1}, t=0\right) \\
C_{2}=0 & \left(h_{1} \leqq x, t=0\right)
\end{array}
$$

染色開始倦， $x=0$ では一定濃度 $C_{s 1}$ に保たれるもの上する。

$$
C_{1}=C_{\mathrm{s} 1} \quad(x=0, t>0)
$$

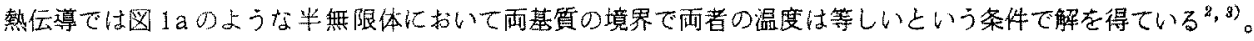

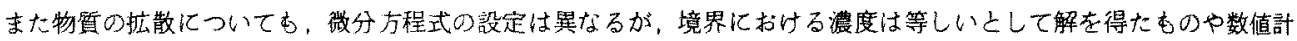
算を行った例がある゙。

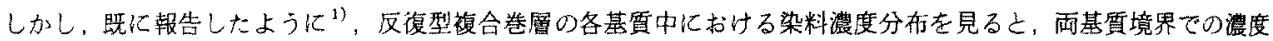

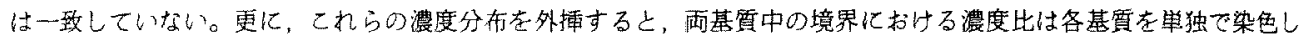

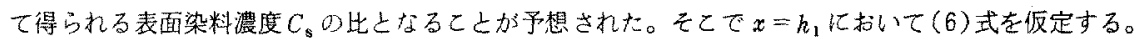

$$
\frac{C_{1}}{C_{2}}=\frac{C_{\mathrm{s} 1}}{C_{\mathrm{s} z}} \quad\left(x=h_{1}, t>0\right)
$$

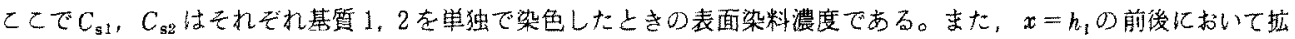
散翼は变わらないあのとして次の条件を入れる。

$$
D_{1} \frac{\partial C_{1}}{\partial x}=D_{2} \frac{\partial C_{2}}{\partial x} \quad\left(x=h_{1}, t>0\right)
$$

なお， $t>0$ において $x \rightarrow \infty$ とをき $C_{2} \rightarrow 0$ とする。

以上の各条件の毛とに(1)，(2)式を解くと，それぞれ(8)，(9)式となる。

$$
\begin{aligned}
& \frac{C_{1}}{C_{\mathrm{s} 1}}=1-\frac{2 \sigma}{\pi} \int_{0}^{\infty} \frac{\sin \alpha x}{\cos ^{2} \alpha h_{1}+\sigma^{2} \sin ^{2} \alpha h_{1}} \frac{\exp \left(-D_{1} \alpha^{2} t\right)}{\alpha} d \alpha \quad\left(0 \leqq x \leqq h_{1}\right) \\
& \frac{C_{2}}{C_{\mathrm{s} 2}}=1-\frac{2}{\pi} \int_{0}^{\infty} \frac{\sigma \cos \mu \alpha\left(x-h_{1}\right) \sin \alpha h_{1}+\sin \mu \alpha\left(x-h_{1}\right) \cos \alpha h_{1}}{\cos ^{2} \alpha h_{1}+\sigma^{2} \sin ^{2} \alpha h_{1}} \frac{\exp \left(-D_{1} \alpha^{2} t\right)}{\alpha} d \alpha \\
& \left(h_{1} \leqq x\right)
\end{aligned}
$$

こてで $\mu=\sqrt{D_{1} / D_{2}}, \sigma=C_{\mathrm{s} 2} / C_{\mathrm{s} 1} \mu$ である。

\section{2 スキン・コア型平板中の染料哄度分布およひ染着量}

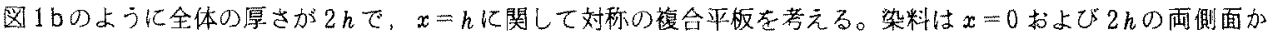

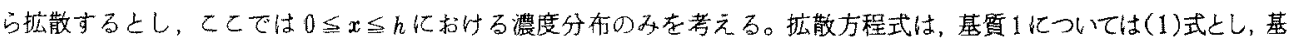

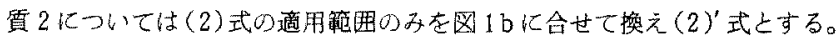

$$
\frac{\partial C_{2}}{\partial t}=D_{2} \frac{\partial^{2} C_{2}}{\partial x^{2}} \quad\left(h_{1} \leqq x \leqq h\right)
$$

初期条件は (3)，(4)式さする。

$$
C_{2}=0, \quad\left(h_{1} \leqq x \leqq h, \quad t=0\right)
$$

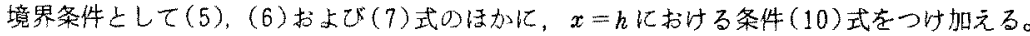

$$
\frac{\partial C_{2}}{\partial x}=0 \quad(x=h, t>0)
$$

これらの条件のもとに(1)，(2)式解くと，それぞれ(11)，(12)式となる。ただし，距離在相対的に表わし，A $=h_{1} / h, X=x / h$ しした。

$$
\begin{aligned}
& \frac{C_{1}}{C_{\mathrm{s} 1}}=1+2 \sum_{n=1}^{\infty} \frac{\cos \mu(1-A) \beta_{n} \cos (A-X) \beta_{n}-\sigma \sin \mu(1-A) \beta_{n} \sin (A-X) \beta_{n}}{g^{\prime}\left(\beta_{n}\right)} \frac{\exp \left(-D_{1} \beta_{n}^{2} t / h^{2}\right)}{\beta_{n}} \\
& \frac{C_{2}}{C_{\mathrm{s} 2}}=1+2 \sum_{n=1}^{\infty} \frac{\cos \mu(1-X) \beta_{n}}{g^{\prime}\left(\beta_{n}\right)} \frac{\exp \left(-D_{1} \beta_{n}^{2} t / h^{2}\right)}{\beta_{n}} \\
& (A \leqq X \leqq A)
\end{aligned}
$$


ここで $g(\beta)$ は (13)式で表わされ，

$$
g(\beta)=\cos \mu(1-A) \beta \cos A \beta
$$$$
-\sigma \sin \mu(1-A) \sin A \beta
$$

$\beta_{n}$ は $g(\beta)=0$ ○正根列,$g^{\prime}\left(\beta_{n}\right)=[d g(\beta) / d \beta]_{\beta=\beta_{n}}$ である。

次に(11)，(12)式老Xについて積分すると，各基啠 におりる染着量を示吉(14)，(15)式が得られる。

$\frac{M_{\mathrm{t} 1}}{M_{\infty 1}}=1+\frac{2}{A}$

$\times \sum_{n=1}^{\infty} \frac{\cos \mu(1-A) \beta_{n} \sin A \beta_{n}+\sigma \sin \mu(1-A) \beta_{n}\left(\cos A \beta_{n}-1\right)}{g^{\prime}\left(\beta_{n}\right)}$

$$
\begin{aligned}
& \times \frac{\exp \left(-D_{1} \beta_{n}^{2} t / h^{2}\right)}{\beta_{n}^{2}} \\
& \frac{M_{\mathrm{t} 2}}{M_{\infty}}=1+\frac{2}{\mu(1-A)} \sum_{n=1}^{\infty} \frac{\sin \mu(1-A) \beta_{n}}{g^{\prime}\left(\beta_{n}\right)} \\
& \times \frac{\exp \left(-D_{1} \beta_{n}^{2} t / h^{2}\right)}{\beta_{n}^{2}}
\end{aligned}
$$

ここで $M_{\mathrm{t} 1}, M_{\mathrm{t} 2}$ はそれぞれ基質 $1 ， 2$ における時間 $t$ 後 门染着量， $M_{\infty 1} ， M_{\infty 2}$ はをれぞれ平衡染着量である。 なお，(8)，(9) 式および(11)，(12) 式において $C_{\mathrm{si}}$ $=C_{\mathrm{s} 2}$ とし，それぞれ相当する定数に置きかえると，熱 伝導の場合に解加れている温度分布式 ${ }^{2,3)}$ 上なる。

\section{3. 実験}

\section{1 供試試料}

前報1に执て用いたセルロースジアセテートフィル ムおよびナイロン6フィルムを使用した。以降をれぞれ Ac， $\mathrm{N}_{6}$ と略す。

染料として水再結晶法により精製した $\boldsymbol{p}$-アミノアソ ベンゼン(PAABと略す)を用いた。

\section{2 スキン・コア型複合体の作製と染色}

水中でガラス棒に一方のフィルムを所定層数巻き，更 にその上に他方のフィルムを巻き，これをスキン・コア 型複合体上した。な招，てれらの椱合体中の染料濃度分 布および染着量を半無限体あるいは平板中のそれらとし て近似できるよゔに，巻層内部のガラス棒として直径 $20 \mathrm{~mm}$ の太いものを使用した。作製した複合体を $95^{\circ} \mathrm{C}$ の水中で 1 時間処理してから, $60^{\circ} \mathrm{C} の \mathrm{PAAB}$ 水溶液(15 $\mathrm{mg} / l)$ 中で所定時間染色した。なお，無限染浴の条件 を満たすため，染着量に応じて染浴舅を2〜4lとした。 染色後，各層加ら染料をメタノールで抽出し，抽出液の 吸光度加染着量を求的た。

3.3 单独フィルム中のPAAB の拡散係数 $D$ 亡表 面染料湿度 $\boldsymbol{C}_{\mathrm{s}}$

$\mathrm{N}_{8}$ およびACの各単独のフィルム巻層を複合巻層の 場合と同様，95Cで 1 時間熱水中で処理したのち，60
Table 1 Diffusion coefficient $D$ and surface concentration $C_{\mathrm{s}}$ of PAAB in each film.

\begin{tabular}{cccc}
\hline & $\begin{array}{c}D \times 10^{8} \\
\left(\mathrm{~cm}^{2} / \mathrm{min}\right)\end{array}$ & $\begin{array}{c}C_{\mathrm{s}} \\
\left(\mathrm{mg} / \mathrm{cm}^{3}\right)\end{array}$ & $\begin{array}{c}\text { Dyeing time } \\
(\mathrm{min})\end{array}$ \\
\hline $\mathrm{N}_{6}$ & 2.31 & 4.04 & 240,1440 \\
$\mathrm{Ac}$ & 0.116 & 11.9 & 2880,7200 \\
\hline
\end{tabular}

Concentration of PAAB; $15 \mathrm{mg} / l$. Volume of the solution; $4 l$, Dyeing temp.; $60^{\circ} \mathrm{C}$.

C Cで染色し，PAABの搪散係数 $D$ 扩よび表面染料濃度

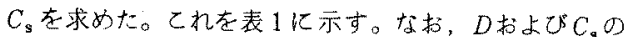
算出には関戸・松井の方法 ${ }^{6)}$ 救よび既報の方法 ${ }^{6)}$ 適用 した。

\section{4. 結果と考繁}

\section{1 スキン・コア型半無限複合体における染料} 濃度分布

ガラス棒にはじめにACを10層巻き，その上にN 5 層巻いた複合巻層を染色し，図 2 亿示す濃度分布を得 だ。この図による上外側から第 5 層の $\mathrm{N}_{6}$ 層よりあ第 6 層のAc層が高濃度であり，両基質の境界で濃度に大き な差を生じているこしがわかる。この濃度分布を，各基 質でとにその表面染料濃度 (表 1 参照)で割り還元型 濃度分布にする上図 3 上なる。この複合巻層の染色で, 最内部の数層は染著されていないので，半無限体しして (8)，(9)式による理論值と比較してみる。図3中の奏 線は各フィルムの単独巻層の染色で得た表1のD， C (8)および (9) 式に代入して算出した理論濃度分布であ る。全体として央測值は埋論曲線によく一致している。

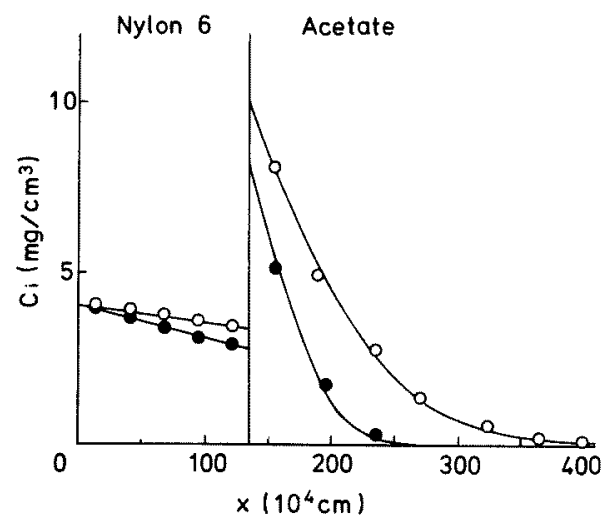

Fig. 2 Concentration distributions of PAAB in the composite film roll $\left(5 \mathrm{~N}_{6}-10 \mathrm{Ac}\right)$ at $60^{\circ} \mathrm{C}$.

$O$ dyed for $4320 \mathrm{~min}$, dyed for $1440 \mathrm{~min}$, - theoretical curves calculated by (8) and (9) 


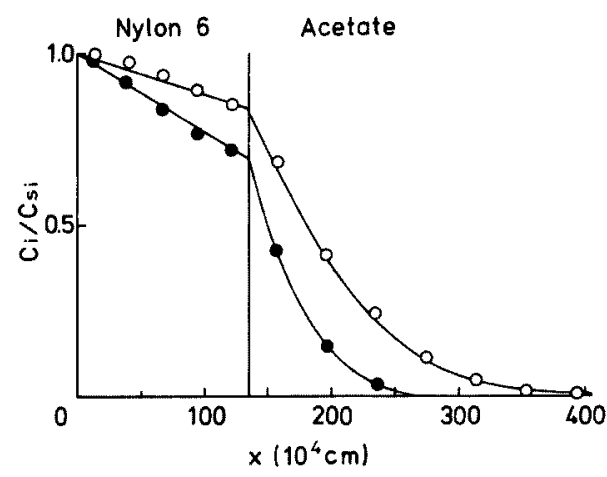

Fig. 3 Reduced concentration distributions of Fig. 2.

図 20 各実線は図3の理論曲線に，対応するC て得た理論曲線であり，乙の図においても実測とのよい 一致が見られる。

したがって（1)，(2)式を解くために仮定した（6)式お よびをの他の境界条件が成立していると考えられる。

Noを内側にした複合巻層では，実験上，半無限複合 体としての濃度分布を得にくいので，ての場合は次項の 複合平板としての解析で检討する。

\section{2 スキン・コア型複合平板における染料湿度 分布}

外側を $\mathrm{AC}$ ，内側を $\mathrm{N}_{6}$ とし，それぞれ 5 層からなる複 合巻層を $5 \mathrm{AC}-5 \mathrm{~N}_{\mathrm{B}}$ と表わす。乙の巻層の染色により， 园 4 の染料濃度分布を得た。やはり両基兵の境界で著し

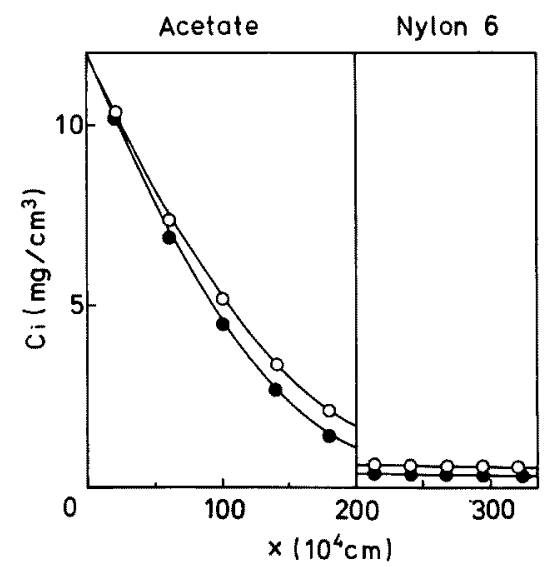

Fig. 4 Concentration distributions of PAAB in the composite film roll $\left(5 \mathrm{Ac}-5 \mathrm{~N}_{6}\right)$ at $60 \mathrm{C}$.

dyed for $7200 \mathrm{~min}$, dyed for $5760 \mathrm{~min}$,

- theoretical curves calculated by (11) and (12)

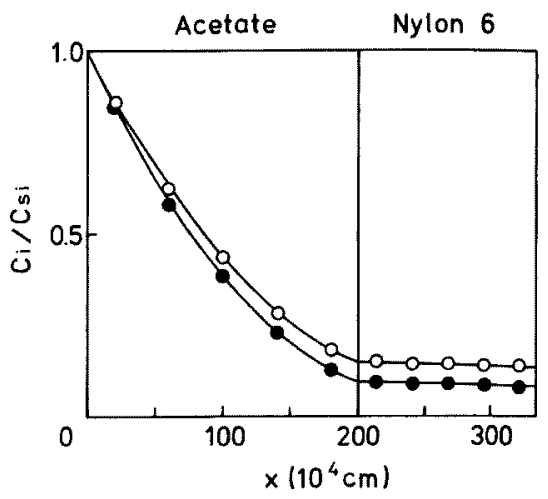

Fig. 5 Reduced concentration distributions of Fig. 4.

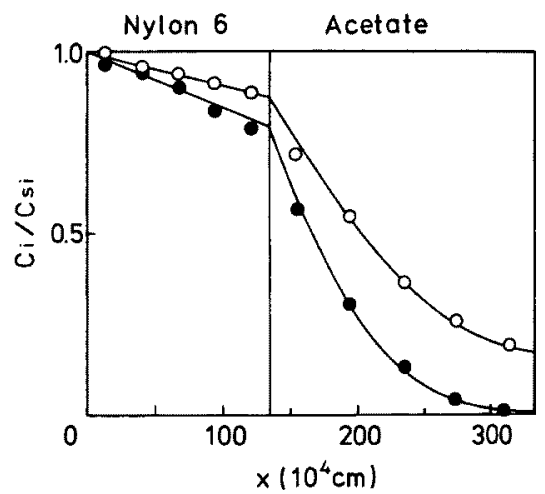

Fig. 6 Reduced concentration distributions of PAAB in the composite film roll $\left(5 \mathrm{~N}_{6}-5 \mathrm{Ac}\right)$ at $60^{\circ} \mathrm{C}$.

0 . dyed for $7200 \mathrm{~min}$, dyed for $2880 \mathrm{~min}$.

- theoretical curves calculated by (11) and (12)

い濃度差が見られ，乙0場合は先の図 2 とは逆に第 6 層 の $\mathrm{N}_{6}$ 中の濃度が激減している。この図を図 3 と同様の 方法で還元型にすると困 5 となる。実線ば䄍合平板とし ての(11)，(12)式に表1のデータを入れて算出した理 論濃度分布である。図 4 の各実線もとれぞれ理論濃度分 布である。いずれも実測值は理諭曲線とよく一政してい る。 $\mathrm{N}_{6}$ を外側とした複合巻層 $\left(5 \mathrm{~N}_{\mathrm{B}}-5\right.$ ACと表わす)に ついても，(11)，(12）式が成立するととを礶加めた。 とれを园6に示す。

以上の結果加ら，乙の場合も，境界条件として仮定し た（6）式およびその他の条件式が成立していると見なさ れる。

\section{3 スキン・コア型複合平板への染茩曲線}


複合平板中のスキンコア各基質への染着量は(14)， (15)式で与えられるから，複合平板全体としての染着 䭪帛估次式となる。

$$
\frac{M_{\mathrm{t}}^{\mathrm{c}}}{M_{\infty}^{\mathrm{c}}}=\frac{M_{\mathrm{t} 1}+M_{\mathrm{tz}}}{M_{\infty 1}+M_{\infty 2}}
$$

ここで $M_{\infty}^{\mathrm{c}}$ は複合平板の平衡染着量である。

表1のデータを用いて(14)，(15)拉よび(16)式から， スキン・コア型複合平板中の染着曲線として図 7 の曲線 1 极よ゙2が得られた。曲線 1 は $5 \mathrm{~N}_{8}-5 \mathrm{Ac}$ ，曲線 2 は $5 \mathrm{Ac}-5 \mathrm{~N}_{6}$ の染着曲線である。この図に上れば，基質 の順序を入れ替えるだけで染着曲線が翼なることがわか

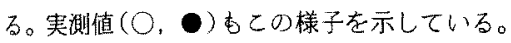

図7亿戈いて理論曲線老詳細に見ると，曲線1は染着 の初期加らすずかに上に型である。一方，曲線 2 は染 着初期ではほとんど直線で，均質な無限平板の染着曲線 $\left(\mathrm{McBain}^{7}{ }^{7}\right.$ 型)と類似している。もし，スキン・コア構造 をあつフィルムの染色で，曲線1あるいは2のような結 果を得た場合，特にスキン・コア構造が意識されないな らば、おえらく，単純にMcBain 型と見なして処理され てしまうであ万う。曲線1は染着初期に扔いて屯直線で 近似するてとはできないか，試みに $M_{\mathrm{t}}^{\mathrm{c}} / M_{\infty}^{\mathrm{c}}=0.5$ の点上 原点を直線で結びその勾配 $I$ から便宜的に $D_{A}=\pi I^{2} h^{2} / 4$ なる值老求好を， $285 \times 10^{-8} \mathrm{~cm}^{2} / \mathrm{min}$ となる。曲線 2 からは $2.17 \times 10^{-8} \mathrm{~cm}^{2} / \mathrm{min}$ が得られた。

今まで本実験化扰りる複合巻層 $5 N_{6}-5 \mathrm{AC}$ 林よび 5 Ac- $5 \mathrm{~N}_{\mathrm{B}}$ をスキン・コア型複合平板の中心加ら片側の

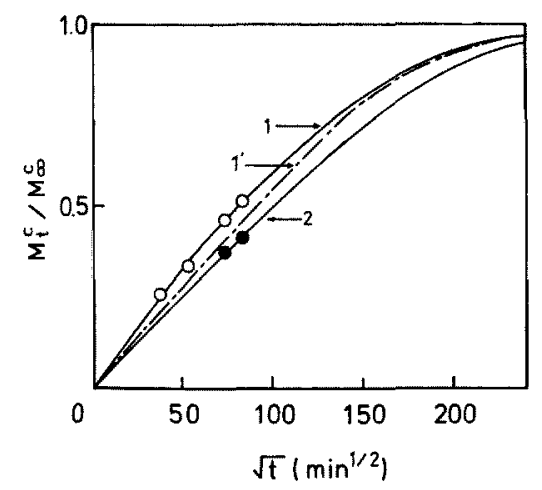

Fig. 7 Dyeing rate of the composite film roll with $P A A B$ at $60^{\circ} \mathrm{C}$.

$0 . \bullet$ experimental $\left(\mathrm{O} 5 \mathrm{~N}_{6}-5 \mathrm{Ac}, \bullet 5 \mathrm{Ac}-5 \mathrm{~N}_{6}\right)$ theoretical (Curve $15 \mathrm{~N}_{6}-5 \mathrm{Ac}$, Curve 2 $5 \mathrm{Ac}-5 \mathrm{~N}_{6}$ )

-.- dyeing rate curve calculated by McBain's equation for $D=2.65 \times 10^{-8} \mathrm{~cm}^{2} / \mathrm{min}$ which is the value of $D_{\mathrm{ov}}$ in $5 \mathrm{~N}_{6}-5 \mathrm{Ac}$.
部分であるとして考察してきた。したかっって，屯し，複 合平板全体を表わ寸可ればそれぞれ $5 \mathrm{~N}_{\mathrm{B}}-10 \mathrm{Ac}-5 \mathrm{~N}_{8}$ 捛よび $5 \mathrm{AC}-10 \mathrm{~N}_{8}-5 \mathrm{Ac}$ となるこのように一方の基 質が他方の基質を挟んでいる場合，乙の平板を通過する 透過量の time lag $L$ は(17)式で表わされる ${ }^{8)}$ 。

$$
\begin{aligned}
L= & \left\{\frac{A}{D_{1}}+\frac{k(1-A)}{D_{2}}\right\}^{-1}\left[\frac { A ^ { 2 } } { D _ { 1 } } \left\{\frac{2 k A+3(1-A)}{3 k D_{1}}\right.\right. \\
& \left.\left.+\frac{k(1-A)}{D_{2}}\right\}+\frac{2(1-A)^{2}}{D_{2}}\left(\frac{A}{D_{1}}+\frac{k(1-A)}{3 D_{2}}\right\}\right] h^{2}
\end{aligned}
$$

ここでk= $C_{\mathrm{s} 1} / C_{\mathrm{s} 2}$ である。

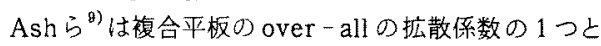
$し て D_{o v}=(2 h)^{2} / 6 L$ を用いて拡散性の評価を行ってい る。

そこで表 1 のデータを用いて $5 \mathrm{~N}_{6}-10 \mathrm{Ac}-5 \mathrm{~N}_{6}$ および $5 \mathrm{Ac}-10 \mathrm{~N}_{6}-5 \mathrm{Ac}$ の $D_{\mathrm{ov}}$ を算出すると，それでれ $2.65 \times$ $10^{-8} \mathrm{~cm}^{2} / \min$ 书よび $2.29 \times 10^{-8} \mathrm{~cm}^{2} / \mathrm{min}$ となった。

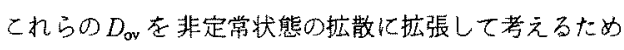
に，均質で厚さ $2 h$ の平板において， $D_{\mathrm{ov}}$ と同じ值を搪 散係数とする染料の染着曲線を描いてみる。すなわち， $D_{\mathrm{ov}}$ の値をMcBainの式》のD代入し染着曲線を計算 する。 $D=2.65 \times 10^{-8} \mathrm{~cm}^{2} / \min$ の場合，図 7 の曲線 $1^{\prime}$ となる。一方， $D=2.29 \times 10^{-6} \mathrm{~cm}^{2} / \mathrm{min}$ の場合は曲線 2 とほとんど重なった。

各基質の $D, C_{\mathrm{s}}$ 亿様々の值を与えて複合平板の染着

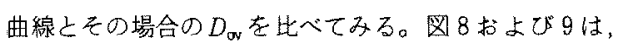
それぞれ基留の並ふ顓序のみを替えてできる複合体に扰 ける染着曲線の一例である。両図に执いて，曲線 1 と2 は基質の順序が互いに逆のものである。曲線 1'および2' はそれぞれ曲線 1 扰よび2を与える复合体のDov在非定 常状態に打ける均質平板への染着に当てはめたあので， 図7 の曲線1'と同様にして得たものである。図8は， 複合体を構成する基質 1 と 2 亿おいて，D，C $C_{\mathrm{s}}$ の両者上 あ異なる場合である。実線 1 と2 との差む，また実線上 対応する 1 点鎖線との差も大である。図 9 は両基質の $C_{\mathrm{s}}$ は等しく，Dのみが異なる場合である。この場合で も曲線 1 と2 は功り異なるし，また，実線と対応する 1 点銷線亡の差屯大きい。图8の曲線 2 および図 9 の曲 線 1.2 について，便宜的な $D_{A}$ を用いて各スキン・コ ア型複合体の染着曲線汇類似した曲線を表わすととがで きるが，図8の曲線】については $D_{A} に よ り$ 類似の曲線は 得られない。したがって、スキン・コア型複合体の場合， $D_{\text {ov }}$ は非定常状態の拡散についてのラフな目安としかな らず， $D_{A}$ も一般性のある搪散性の指標にならないであ ろう。

困8の曲線1はシグモイド型であり，スキン・コア型 


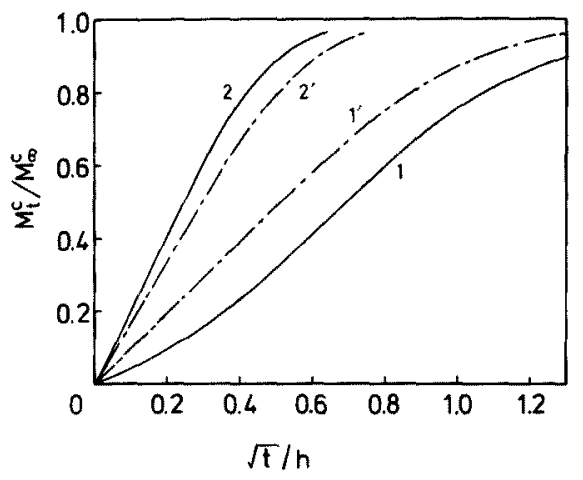

Fig. 8 Variation of dyeing rate curves calculated by $(14) \sim(16)$ with the sequence of two substrates.

substrate 1 substrate $2 \quad A \quad D_{\text {Ov }}$ $\begin{array}{llllll}D_{1} & C_{\mathrm{s} 1} & D_{2} & C_{\mathrm{s} 2} & \text { calc. using } \mathrm{L}\end{array}$ $\begin{array}{lllllll}\text { Curve } 1 & 4 & 1 & 1 & 10 & 0.5 & 0.742\end{array}$ $\begin{array}{lllllll}\text { Curve } 2 & 1 & 10 & 4 & 1 & 0.5 & 2.23\end{array}$

- - - dyeing rate curves calculated by McBain's equation for $D=0.742$ (Curve $1^{\prime}$ ), for $D=$ 2.23 (Curve 2')

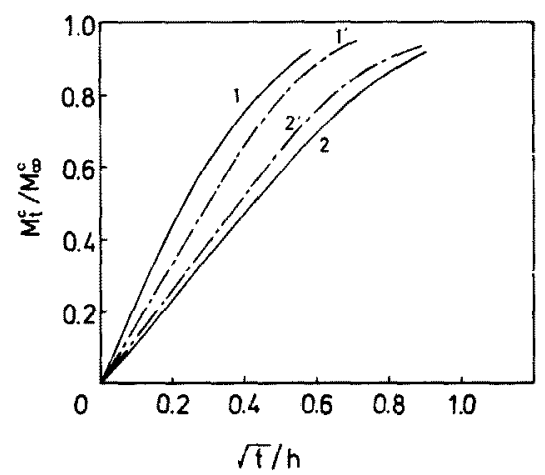

Fig. 9 Variation of dyeing rate curves calculated by $(14) \sim(16)$ with the sequence of two substrates.

substrate 1 substrate $2 A \quad D_{\text {Ov }}$ $\begin{array}{lllll}D_{1} & C_{\mathrm{S} 1} & D_{2} & C_{\mathrm{S} 2} & \text { calc. using L }\end{array}$ $\begin{array}{lllllll}\text { Curve } 1 & 4 & 1 & 1 & 1 & 0.5 & 2.19\end{array}$ $\begin{array}{lllllll}\text { Curve } 2 & 1 & 1 & 4 & 1 & 0.5 & 1.35\end{array}$

---dyeing rate curves calculated by McBain's equation for $D=2.19$ (Curve $1^{\prime}$ ), for $D=$ 1.35 (Curve $2^{\prime}$ )

複合平板の染着曲線はその他様々の形をとるものと思わ れる。そてで、つぎに，一方の基質のDおよびC を系 統的に変えるととにより，染著曲線の変化を調へた。る の一例を四10に示す。との唕では，いずれも基質10

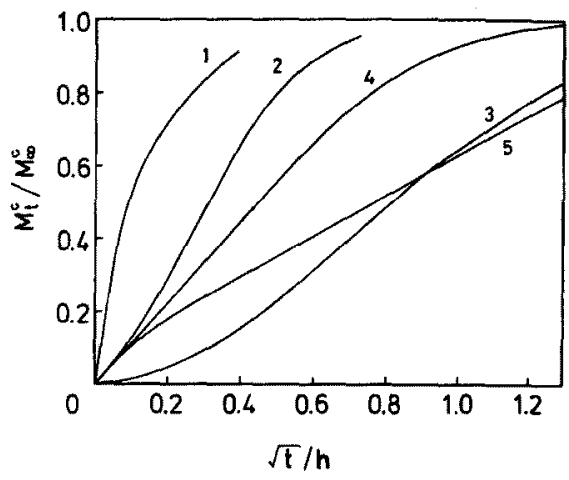

Fig. 10 Variation of dyeing rate curves calculated by $(14) \sim(16)$ with $D_{2}$ and $C_{\mathrm{s} 2}$. substrate 1 substrate $2 A$

$\begin{array}{cccccc}\text { Curve } 1 & 1 & 1 & 4 & 0.1 & 0.1\end{array}$

$\begin{array}{llllll}\text { Curve } 2 & 1 & 1 & 4 & 1 & 0.1\end{array}$

$\begin{array}{llllll}\text { Curve } 3 & 1 & 1 & 4 & 10 & 0.1\end{array}$

$\begin{array}{llllll}\text { Curve } 4 & 1 & 1 & 1 & 1 & 0.1\end{array}$

$\begin{array}{llllll}\text { Curve } 5 & 1 & 1 & 0.25 & 1 & 0.1\end{array}$

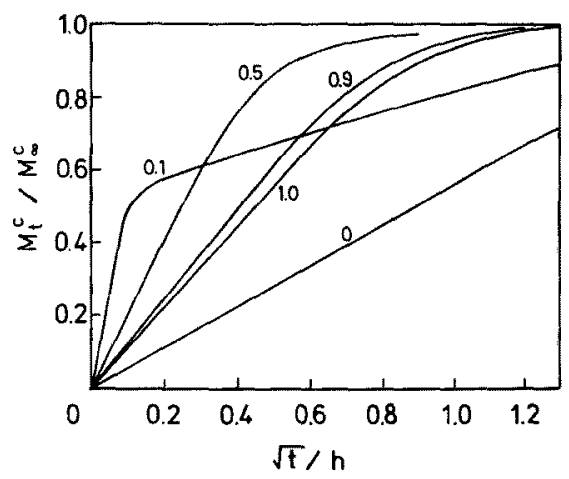

Fig. 11 Variation of dyeing rate curves calculated by (14) $-(16)$ with $A$.

$D_{1}=1, C_{\mathrm{s} 1}=1, D_{2}=0.25, C_{\mathrm{s} 2}=0.1$, the numbers on the curves are the values of $A$.

拿さ分率 $A$ を $0.1 ， D_{1}=1 ， C_{\mathrm{s} 2}=1$ とし， $D_{2} ， C_{\mathrm{s} 2}$ のみ ををれぞれ変えたすのである。

また， $D_{1} ， C_{\mathrm{s} 1} ， D_{2} ， C_{\mathrm{s} 2}$ がそれぞれ一定の值です， 各基質の厚さが変われば染着曲線が变化する。これ在図 11 亿示した。图10および11の各曲線についても， $D_{A}$ $D_{\mathrm{ov}}$ を求めてみたが、これらはやはり非定常状態の应散 性を端的に示すあのではない。

一般に，キャスト法によって整膜されたフィルムは容 媒の蒸発する面ともう一方の面で構造が異なるといわ $れ^{10)}$ ，湿式製膜ではスキン・コア構造となるとと，更に 
スキン層とコア層で染色性が異なることも知られてい る゙。ままた射出成形膜においても表面から内部まで層

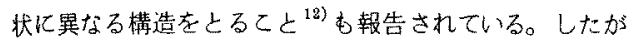
って，䋐維あるいはフィルムを均質なすのよして，染着 曲線加拡散係数在求め上うよする場合，以前加ら指摘 されているとおり，試料の㹡散方向についての均質性に む十分注意が払われるべきであるう。

\section{ま亡め}

スキン・コア型襀合巻層の染色により，複合体内部に おりる染料濃度分布を測定した。

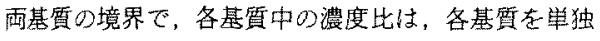
で染色したときに得られる表面染料濃度の比となるとと を仮定し，染料濃度分布式を導いた。この理諭濃度分有 と夷測值とはよく一致し，仮定した境界条件が成立する ことがわかった。

更に，涶度分布式から染着量の式を導き，スキン・コ ア型複合体では，基質の恶ふ順序によって染着曲線が異 なることを示した。

また，2種の基質に括ける搪散係数，表面染料濃度， 各基質の厚さ分率に上る染着曲線の変化を系統的に図示 した。

本報の一部は第 19 回染色化学討論会（昭和 52 年 6 月
東京)において発表したものである。

\section{文献}

1) 丁子, 唐沢; 繊学誌, 34, T-207, (1978)

2) Carslaw, Jaeger; "Conduction of Heat in Solids" 2nd ed., Oxford Univ. Press (1959) p.319

3）川下研介；个熱伝導論」, オーム社(1966), P.84

4) J. Crank; "The Mathematics of Diffusion" 2nd ed., Oxford Univ. Press (1975) p.149, 197

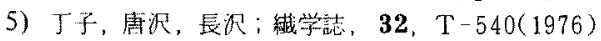

6) 関户，松井；瀻学誌，20，778(1964)

7) R.H. Peters; "Textile Chemistry III", Elsevier, Amsterdam, (1975), p.159

8) R.M. Barrer; "Diffusion in Polymers" Chap. 6, (ed. by J. Crank and G.S. Park), Academic Press, London (1968)

9) R. Ash, R. M. Barrer, J.H. Petropoulos; Brit. J. Appl. Phys., 14, 854 (1963)

10）たとえば，中村孝一; 「化学絨維の紡采とフィル 么成形（II）」(高分子学会編），地人慧館 (1970)， P. 342

11)たとえば，瀻維学会編；「纎維物理学」，丸善 (1962), P. 103

12) Z. Mencik, D. R. Fitchmun; J. Polym. Sci. Polym. Phys. ed., 11, 973 (1973) 